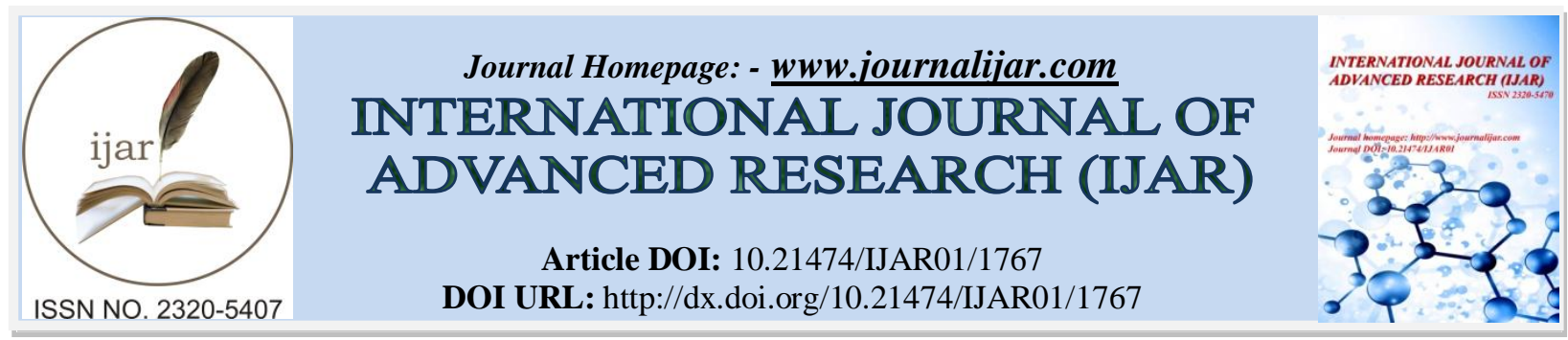

RESEARCH ARTICLE

\title{
INTEGRATED NUTRIENT MANAGEMENT FOR FOOD SECURITY AND ENVIRONMENTAL QUALITY.
}

\section{Ibajanai Kurbah.}

PhD scholar, Department of Soil Science, CSK Himachal Pradesh Agricultural University, Palampur-176062.

\section{Manuscript Info}

Manuscript History

Received: 12 August 2016

Final Accepted: 26 September 2016

Published: October 2016

Key words:-

Fertilizers, integrated nutrient

management, soil quality

\section{Abstract}

The challenge that the world is facing has been to maximize food production to feed the increasing population. Further, agriculture at present encompasses many problems such as stagnating food-grain production, multi- nutrient deficiency, declining fertilizer response, reduction in land availability for cultivation, environmental pollution and land degradation. To manage long term soil fertility, productivity as well as environment quality, integration of organic and inorganic fertilizer can be the most sustainable practices to adopt. Several nutrient managements have been practiced; however, current studies on long term experiments indicated that integrated nutrient management proved to be the best approach for sustainable crop production as well as reducing environmental pollution. This paper explains the importance and strategies of integrated nutrient management.

Copy Right, IJAR, 2016,. All rights reserved.

\section{Introduction:-}

The current world population is 7.2 billion and is expected to be around 9.6 billion by 2050 (UN, 2014). India is the second most populous country in the world and its population is projected to be 1.66 billion by 2050 (US, 2014). As population increases, there is pressure on the existing cultivable lands to produce more food to meet increasing demands and other needs of humans such as land for settlements and infrastructure development. Continuous cultivation of the land results in reduction of inherent soil nutrients.

Fertilizers have played a major role in increasing crop productivity. Overuse of these chemical fertilizers has resulted in many problems that include underground water pollution and greenhouse gas emission; and now attention has been turned to the use of organic fertilizer sources, alone and in combination with chemical fertilizers, not only to improve yields but also to maintain and improve the cultivated land's physical, chemical, and biological properties. Developing countries face problems in their agricultural production not from overuse but also from underuse of chemical fertilizers which causes multi-nutrient deficiency and reduction in fertilizer response.

The challenge for agriculture will not only be to meet the food needs of earth's expanding population, but also undertake it in a manner that is sustainable for present and future generations. There is hardly any scope for further expansion in area under cultivation, so additional food grain production has to come only through increased productivity. Declining soil fertility and mismanagement of plant nutrients have made this task more difficult.

Corresponding Author:- Ibajanai Kurbah.

Address:- PhD scholar, Department of Soil Science, CSK Himachal Pradesh Agricultural University, Palampur-176062. 


\section{Fertilizer use:-}

Fertilizer is any organic or inorganic material of natural or synthetic origin that is added to soil to supply one or more plant nutrients essential to plant growth. Fertilizers reduce pressure on land by leaving less fertile land for other purposes. By making land more productive, fertilizers greatly increase the value of land making it possible to cater all our needs even including recreation and amenity. Land is a scarce resource and has to provide for all the competing demands of modern society. Fertilizers have allowed farmers to continuously achieve high yields on same land for many years, eliminating need for clearing new lands.

It is estimated that around half of the current global crop yield is attributable to commercial fertilizer use. Since 1960, world fertilizer use has risen by around 3.2\% per year whereas world food grain production has risen by $2.4 \%$ per year during same period. China and India together accounts for $47 \%, 48 \%$ and $28 \%$ of the world consumption of $\mathrm{N}, \mathrm{P}_{2} \mathrm{O}_{5}$, and $\mathrm{K}_{2} \mathrm{O}$ respectively. In India the contribution of fertilizers to total food grain production has increased from $1 \%$ in 1950 to $58 \%$ in 1995 . Between 1951- 52 and 2013-14, the annual consumption of $\mathrm{N}^{+} \mathrm{P}_{2} \mathrm{O}_{5}+\mathrm{K}_{2} \mathrm{O}$ increased from about 66 thousand MT to 24.482 million MT. In 2013, N contributed to 66\% of total fertilizer consumption in India, while $\mathrm{P}_{2} \mathrm{O}_{5}$ and $\mathrm{K}_{2} \mathrm{O}$ share was 26 and 8\% respectively (Majumdar et al., 2014).

\section{Current problems in India:-}

1. Stagnating food-grain production

2. Multi- nutrient deficiency

3. Imbalances of fertilizer use

4. Declining fertilizer response

5. Change in land- man ratio over years

6. Environmental damage

7. Land degradation

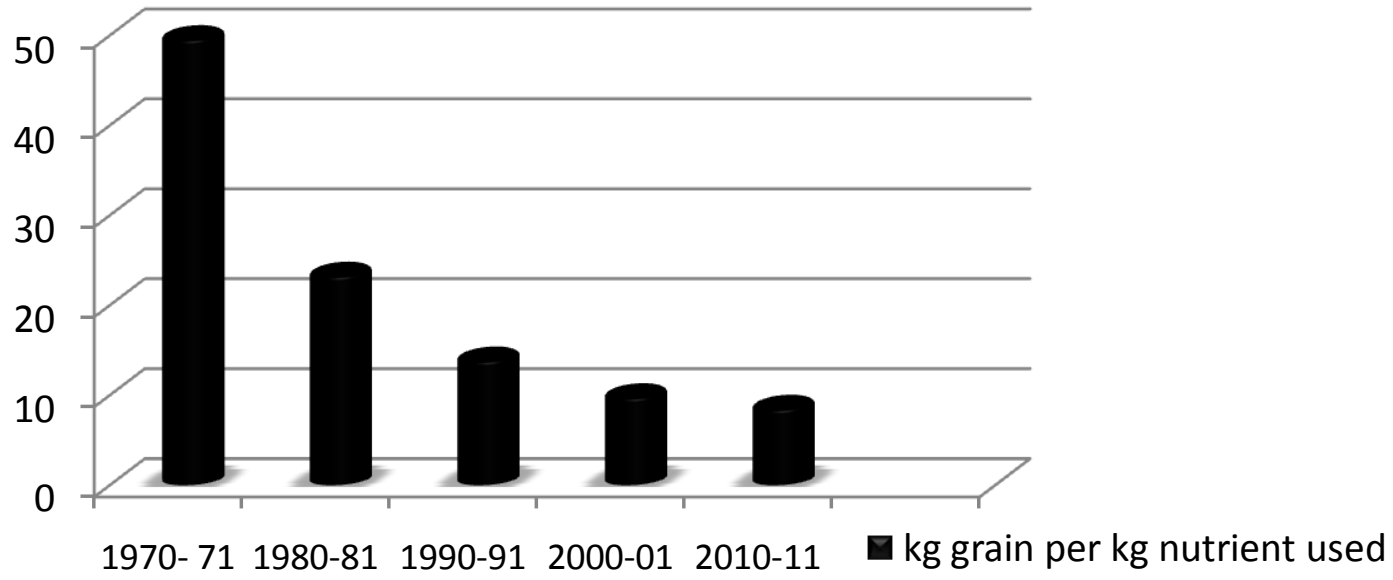

Fig 1:- Declining fertilizer response in India.

As per the study of Rao et al. (2015) food grain production of India has reached a stagnating phase mainly because of decline of soil health. Indian soils are deficient in major plant nutrients. With increase in agriculture intensification, the soils are continuously depleted of secondary plant nutrients also such as sulphur and micronutrients. A reduction in crop response to fertilizer consumption is also widely noticed across several production systems (Fig 1). The constant decline in factor productivity in respect of fertilizer use is a conspicuous indicator of soil health deterioration. Imbalanced use of fertilizers is one of the major causes of soil health decline. The ratio of $\mathrm{N}: \mathrm{P}_{2} \mathrm{O}_{5}: \mathrm{K}$ at the all India level is presently at abysmally distorted level of 8.0:2.7:1 as compared to the ideal level of 4:2:1. The highly imbalanced use of plant nutrients adversely affects the soil health and long term soil productivity. 


\section{Environmental Damage:- \\ Effect on water:-}

The over-supply of nutrients from chemical fertilizers in excess of plant needs and in the absence of a mechanism to bind the nutrients to the soil, can lead to environmental contamination. Soil nitrate concentrations in excess of plant absorption needs, for example, allow the soluble nitrate to be carried away in ground water to contaminate surface waters and underground aquifers. Leaching and run-off of nitrogen and phosphorus into rivers, lakes, and inlets, can cause eutrophication- an excess accumulation of nutrients in water that promotes algal over-production. Around 1.6 million people in the U.K. are supplied with water with nitrate levels that exceed guidelines. Danish, Dutch and German coastal regions exhibit signs of eutrophication (Bockman et al. 1990) and according to the USDA, nearly two-thirds of the pollution in U.S. rivers has been attributed to agriculture with close to 60 percent of the pollution in lakes caused by runoff from excess plant nutrients.

\section{Effect on soil:-}

Soil structure is regarded as an indicator in agricultural productivity. $\mathrm{NaNo}_{3}, \mathrm{NH}_{4} \mathrm{NO}_{3}, \mathrm{KCI}, \mathrm{K} 2 \mathrm{SO}_{4}, \mathrm{NH}_{4} \mathrm{Cl}$ demolish the soil structure. Soil structure deterioration is difficult to obtain good crop growth. Particularly high level of sodium and potassium containing fertilizers, make a negative impact on soil $\mathrm{pH}$ and soil structure. Continuous use of acid-forming nitrogen fertilizers causes a decrease in soil $\mathrm{pH}$. Basic use of fertilizers in the soil leads to an increase in $\mathrm{pH}$.

\section{Effect on air:-}

In calcareous and alkaline soils, when in excess to plant needs, nitrogen escapes into the atmosphere as nitrogen gas and various nitrous oxides. In the upper atmosphere, nitrous oxides react to form acid rain which can be damaging to crops, acidifies soil and water, and contributes to property damage. Also, it can damage organisms that they live in both lakes and reservoirs. Around two-thirds of total nitrous oxide emissions are attributed to agriculture.

\section{Land degradation:-}

The Food and Agriculture Organization (FAO, 1980) defines the concept of land degradation as the deterioration or total loss of the productive capacity of the soils for present and future use. It has been estimated that about 1.9 billion hectares of land worldwide (an area approximately the size of Canada and the USA) are affected by land degradation (United Nations, 1997). In India, 120.7 million ha of total geographical area is affected by various kinds of land degradation (Chaudhary et al., 2015).

Soils will need to be managed more effectively and efficiently for agriculture to be sustained through the year 2050 and beyond.

\section{Integrated nutrient management:-}

Integrated nutrient management means combined application of different sources of plant nutrients like organics, inorganic and bio-fertilizers for sustainable crop production without degrading the natural resources on long term basis. The three main components of INM as defined by FAO, 1998 are:

1. Maintain or enhance soil productivity through a balanced use of fertilizers combined with organic and biological sources of plant nutrients

2. Improve the stock of plant nutrients in soils

3. Improve the efficiency of plant nutrients, thus, limiting losses to the environment

Integrated plant nutrient management (IPNM) is an important component of sustainable agricultural intensification, as well as crop, pest, soil, and water management. IPNM centers on the management of soils in their capacity to be a storehouse of plant nutrients that are essential for vegetative growth. The goal of IPNM is to integrate the use of all natural and man-made sources of plant nutrients, so as to increase crop productivity in an efficient and environmentally benign manner, without diminishing the capacity of the soil to be productive for present and future generations.

\section{Objectives of Integrated Nutrient Management:-}

1. To maintain fertility and physico-chemical properties of soil

2. To recycle and use of organic wastes

3. Encouragement of the judicious use of chemical fertilizers, green leaf manures and bio-fertilizers for higher productivity 
4. Creation of positive nutrient balance in soil

5. To avoid over exploitation of natural resources

6. Maximization of nutrient use efficiency

7. Environmentally safe and eco friendly sustainable agriculture

8. To reduce expenditure on cost

9. To meet the social and economic aspirations of the farmers lower cost with high productivity and profitability

10. To protect soil health.

\section{Role of integrated nutrient management for sustaining production:-}

The role of fertilizers in boosting crop production has already been proved and they have become so essential that the cultivation of present-day without them is rather a dream. The overall strategy for increasing crop yields and sustaining them at a high level must include an integrated approach to the management of soil nutrients. In 2006, Ram and Mir recorded an increase of 59.7 and $17.0 \%$ in wheat grain yield with the application of 10 tonnes FYM+120 kg N/ha over the control and 10 tonnes FYM + $100 \mathrm{~kg} \mathrm{~N} /$ ha respectively. This increase in the yield was mainly owing to the improvement in growth as well as yield-attributing characters, as the application of FYM and nitrogen improves the fertility status which results in the better utilization of nutrients by the wheat crop. Application of Azospirillum and Azotobacter had significantly increased the plant height, number of tillers and drymatter accumulation over the uninoculated control. However, their combined application (Azospirillum + Azotobacter) proved significantly better than the individual application as well as the control for these growth parameters. Increase in yield attributes and yield of wheat with biofertilizers might be owing to increased supply of plant hormones by the micro-organisms or by roots as a result of reaction to microbial colonization.

Amoah et al. (2012) recorded for two cropping years (maize) and observed that the inorganic and organic combined treatments productivity was at par with the sole inorganic fertilizer-treated plots (Table 1). This shows the potential of cow dung to supply nutrients to substitute for those of inorganic fertilizers for crop productivity. Even at $50 \%$ reduction of inorganic fertilizer with $10 \mathrm{t} \mathrm{ha}^{-1}$ cow dung supplementing, crop growth and productivity were not negatively affected.

A long term experiment carried out by Upadhyay and Vishwakarma (2014) at Jabalpur found that the application of $50 \% \mathrm{NPK}+50 \% \mathrm{~N}$ substituted through green leaf manuring (GLM) to rice resulted in the maximum grain yield, which was $148 \%$ higher over the control followed by $50 \% \mathrm{NPK}+50 \% \mathrm{~N}$ substituted through FYM (135\%) and for rabi wheat the treatment receiving 50\% NPK $+50 \% \mathrm{~N}$ substituted through GLM (2.98t/ha) and FYM (2.85t/ha) enhanced the productivity of wheat by 282 and $259 \%$ respectively. This improvement in seed yield was owing to incorporation of GLM and FYM, attributed to its ability to proper nutrient supply throughout the growing season. The treatment receiving suboptimal dose of nutrients, i.e. 50 and $75 \%$ or even $100 \%$ without organic manures, though the yield was higher over the control, but these treatments showed declined yield and the sulphur and zinc deficiency. Similar results were observed by Sharma and Subehia (2014), Palampur under rice- wheat cropping system.

Table 1:- Effects of treatments on yield and yield components of maize.

\begin{tabular}{|l|c|c|c|c|}
\hline \multirow{2}{*}{ Treatment } & \multicolumn{2}{|c|}{ No. of grain per cob } & \multicolumn{2}{c|}{ Yield $\left(\mathrm{g} / \mathrm{m}^{2}\right)$} \\
\cline { 2 - 4 } & 2007 & 2008 & 2007 & 2008 \\
\hline Control & $545.2 \mathrm{a}$ & $473.3 \mathrm{~b}$ & $528.9 \mathrm{a}$ & $513.1 \mathrm{~b}$ \\
\hline $100 \%$ NPK & $620.1 \mathrm{a}$ & $674.0 \mathrm{a}$ & $594.0 \mathrm{a}$ & $747.1 \mathrm{a}$ \\
\hline Cow dung only applied @ 20 t/ha & $614.1 \mathrm{a}$ & $562.6 \mathrm{ab}$ & $586.8 \mathrm{a}$ & $623.4 \mathrm{ab}$ \\
\hline $75 \%$ NPK + cow dung @ 5 t/ha & $610.5 \mathrm{a}$ & $622.5 \mathrm{a}$ & $543.9 \mathrm{a}$ & $747.0 \mathrm{a}$ \\
\hline 50\% NPK + cow dung @ 10 t/ha & $616.1 \mathrm{a}$ & $621.5 \mathrm{a}$ & $594.1 \mathrm{a}$ & $710.3 \mathrm{a}$ \\
\hline $\begin{array}{l}\text { Means followed by the same letters in a column are not significantly different from each } \\
\text { other according to Scheff's test at the 5\% level of probability. }\end{array}$
\end{tabular}

At the experimental field, Bhubaneswar, the highest potato tubers growth and yield were obtained with the application of 50\% RDF through inorganic and remaining 50\% RDF through FYM, which were at par with the crop receiving 50\% RDF through inorganic and remaining 50\% RDF through vermicompost or neem cake (Mohanty et al., 2014). Beneficial effect of integrated use of organic and inorganic sources of plant nutrients improved the soil physical condition and higher availability of nutrients which, in turn, resulted to higher tuber yield. 
Parmar (2014) found that the mean total productivity of frenchbean- frenchbean- cauliflower $\left(53.9 \mathrm{t} \mathrm{ha}^{-1}\right)$ and cauliflower- cauliflower- pea $\left(69.0 \mathrm{t} \mathrm{ha}^{-1}\right)$ was highest under 100\% NPKB + FYM and lowest under control. Higher productivity of vegetable crops in a system as a result of combined application of fertilizers and FYM could be explained on the grounds that addition of organic manure in the soil improves the soil physical and chemical properties which encourage better root development, increased nutrient uptake and water holding capacity which leads to higher yield and better fruit quality.

Kumawat et al. (2015) found that the harvest index of pigeonpea and blackgram was significantly higher in $100 \%$ $\mathrm{RDF}+50 \% \mathrm{RDN}$ (vermicompost) $+5 \mathrm{~kg} \mathrm{Zn} / \mathrm{ha}$ and is at par with $50 \% \mathrm{RDF}+100 \% \mathrm{RDN}+5 \mathrm{~kg} \mathrm{Zn} / \mathrm{ha}$ over control. The combined application of organic and inorganic fertilizers was more effective due to complimentary in their response.

\section{Role of integrated nutrient management for maintaining soil quality:-}

Soil quality and its importance in agricultural sustainability and environmental ecology have been recognized in recent years. Soil quality is most simply defined as "the capacity of the soil to function". Important soil functions include: water flow and retention, solute transport and retention, physical stability and support; retention and cycling of nutrients; buffering and filtering of potentially toxic materials; and maintenance of biodiversity and habitat. A broader, ecologically-based approach was presented by Doran et al. (1996) where they defined soil health as "the continued capacity of soil to function as a vital living system, within ecosystem and land-use boundaries, to sustain biological productivity, maintain the quality of air and water environments, and promote plant, animal, and human health."

Singh (2007) evaluated quantitatively the soil quality changes for three cropping seasons. Soil quality evaluations using data prior to INM treatment in 2001 and after 3 years of INM treatment showed that soil quality at this experiment was not very high. Results of three years, data indicate that the quality of soils of the trial area had improved with Relative Soil Quality Index above zero. Soil quality under INM trial was increased by 12-19 units as compared to 7-9 unit of farmer's practice of farming. In 2001, there was no class I, II and III type soil, and experimental plots were with class IV type soil. After INM treatment for 3 years, areas of class IV were improved to class III. This indicates that INM efforts improved low quality soils, but some high quality soils were not maintained. The reason is the INM study only focused on surface soil properties and the soil functions which support plant growth. The soil quality in terms of physical properties, fertility status, organic matter etc., has been increased up to $60 \%$.

Aulakh (2010) reported the reduction of gaseous loss of $\mathrm{N}$ under the conjunctive use of inorganic with organics i.e, green manure and crop residues. There was improvement of physical, chemical and biological properties of soil too under integrated nutrient management.

Kharche et al. (2013) have observed that the long-term effect of continuous integrated nutrient management and adoption of easily available options of practicing green manuring, addition of crop residues and organic manures in conjunction with chemical fertilizers in balanced form are efficient for building- up of the active carbon fractions in soil which is important for enhancing soil quality. The organic matter in soils enhanced under integrated nutrient management was found to be a key attribute of soil quality which has shown far-reaching effects on physical, chemical and biological properties of soil indicating necessity of addition of crop residues and organic manures in conjunction with chemical fertilizers for securing soil quality under intensified agriculture The physical properties of soil viz., bulk density, aggregate stability, hydraulic conductivity, and mean weight diameter and water retention were significantly improved due to integration of chemical fertilizers with organics as compared to only chemical fertilizers. Bulk density was considerably reduced from initial value of 1.32 to $1.20 \mathrm{Mg} \mathrm{m}^{-3}$ due to integration of chemical fertilizers with organics which was significantly lower as compared to that of control and only chemical fertilizers. The reduction in bulk density of soil under integrated nutrient management is due to better aggregation, increased porosity and improvement in soil structure caused due to increase in soil organic matter. The initial organic carbon content of the soil during $1984-85$ was $6.4 \mathrm{~g} \mathrm{~kg}^{-1}$ which was increased only to $6.8 \mathrm{~g} \mathrm{~kg}^{-1}$ at $50 \% \mathrm{RDF}$ $+50 \% \mathrm{~N}$ (FYM), suggesting marginal build-up in organic carbon content. The soil organic carbon showed declining trend from its initial value of $6.4 \mathrm{~g} \mathrm{~kg}^{-1}$ during 1984 to $5.2 \mathrm{~g} \mathrm{~kg}^{-1}$ under use of only chemical fertilizers. Similarly, Gathala et al. (2007) reported the improvement of soil bulk density, water stable aggregates, cation exchange capacity and soil organic carbon under long term fertilizer experiments at Udaipur under maize-wheat cropping system. 
Gabhane et al. (2014) observed that the application of 50\% RDF + FYM @ 15 t/ha recorded significantly better soil quality index (SQI) along with significant improvement in physical, chemical and biological properties and sustaining the cotton productivity in rainfed Vertisols under semi-arid region of Maharashtra.

In India, long-term studies at different locations indicated that INM helped in enhancing the efficiency of nutrients (Das et. al., 2015) which could therefore minimise nutrient losses to the environment.

\section{Common constraints encountered by the farmers in adoption of INM technology:-}

1. Non availability of FYM

2. Difficulties in growing green manure crops

3. Non-availability of biofertilizers

4. Non-availability of soil testing facilities

5. High costs of chemical fertilizers

6. Non-availability of water

7. Lack of knowledge and poor advisory services

8. Non-availability of improved seeds

9. Soil conditions

\section{Conclusion:-}

Integrated nutrient management is vital for sustaining food production. Use of organic, biofertilizers and green manures along with fertilizers has been found effective in improving \& maintaining soil fertility, increasing nutrient use efficiency so maximizing productivity in different cropping system. Therefore, an integrated approach for the management of most important natural resource base is extremely important which would ensure efficient use of onfarm generated organic manures along with mineral fertilizers, thereby ensuring sustainable crop production. Besides sustaining crop production, INM decreases the heavy use of inorganic fertilizers alone and improves efficiency of nutrients thereby reducing losses to the environment which ultimately checks environmental pollution. INM can therefore be used as a part of global strategy to ensure food security and protect the environment.

\section{References:-}

1. Amoah, A.A., Senge, M., Miyagawa, S. and Itou, K. (2012): Effects of Soil Fertility Management on Growth, Yield, and Water-Use Efficiency of Maize (Zea mays L.) and Selected Soil Properties. Communications in Soil Science and Plant Analysis 43: 924-935.

2. Aulakh, M.S. (2010): $19^{\text {th }}$ World Congress of Soil Science, Soil Solutions for a changing world. Brisbane, Australia.

3. Bockman, O.C., Kaarstad, O., Lie, O.H. and Richards, I. (1990): Agriculture and fertilizers: Fertilizers in perspective. Oslo: Norsk Hydro.

4. Chaudhary, S.K., Islam, A., Biswas, P.P. and Sikka, A.K. (2015): Natural resource management- problems and prospects. Indian Journal of fertilizers 11 (4): 16-23.

5. Das, D., Dwivedi, B.S. and Meena, M.C. (2015): Integrated nutrient management for improving soil health and crop productivity. Indian Journal of Fertilizers 11(4): 64- 83.

6. Doran, J.W., Sarrantonio, M. and Liebig, M.A. (1996): Soil health and sustainability. Adv. Agron. 56:1-54.

7. FAO. (1980): Report on the Second FAO/UNFPA Expert Consultation on Land Resources for Populations of the Future. FAO, Rome.

8. FAO. (1998): Guide to efficient plant nutrient management, Rome: Land and Water Development Division Food and Agricultural Organization of the United Nations.

9. Gabhane, V.V., Sonune, B.A. and Katkar, R.N. (2014): Long term effect of tillage and integrated nutrient management on soil quality and productivity of rainfed cotton in Vertisols under semi-arid conditions of Maharashtra. Indian Journal of Dryland Agriculture Research and Development 29(2): 71-77.

10. Gathala, M.K., Kanthaliya, P.C., Verma, A. and Chahar, M.S. (2007): Effect of Integrated Nutrient Management on Soil Properties and Humus Fractions in the Long-term Fertilizer Experiments. Journal of the Indian Society of Soil Science 55(3): 360-363.

11. Kharche, V.K., Patil, S.R., Kulkarni, A.A., Patil, V.S. and Katkar, R.N. (2013): Long-term Integrated Nutrient Management for Enhancing Soil Quality and Crop Productivity under Intensive Cropping System on Vertisols. Journal of the Indian Society of Soil Science 61(4): 323-332. 
12. Kumawat, N., Singh, R.P., Kumar, R., Yadav, T.P. and Om, H. (2015): Effect of integrated nutrient management on productivity, nutrient uptake and economics of rainfed pigeonpea (Cajanus cajan) and blackgram (Vigna mungo) intercropping system. Indian Journal of Agricultural Sciences 85 (2): 171-6.

13. Majumdar, K., Dey, P. and Tewatia, R.K. (2014): Current nutrient management approaches- issues and strategies. Indian Journal of fertilizers 10 (15):14-27.

14. Mohanty, M., Nanda, S.S. and Barik, A.K. (2014): Improving potato (Solanum tuberosum) yield and soil health through integrated nutrient management approach in east coast climatic conditions of India. Indian Journal of Agricultural Sciences 84 (11): 1395-1400.

15. Parmar, D.K. (2014): Yield produce quality and soil health under vegetable cropping systems as influenced by integrated nutrient management in mid-hill zone of Himachal Pradesh. Journal of the Indian Society of Soil Science 62(1): 45-51.

16. Ram, T. and Mir, M.S. (2006): Effect of integrated nutrient management on yield and yield attributing characters of wheat (Triticum aestivum). Indian Journal of Agronomy 51(3): 189- 192.

17. Rao, A.S., Lenka, N.K., Biswas, A.K. and Ramesh, K. (2015): Soil health enhancement- issues and strategies. Indian Journal of fertilizers 11(4):28-37.

18. Sharma, U. and Subehia, S.K. (2014): Effect of Long-Term Integrated Nutrient Management on Rice (Oryza sativa L.) - Wheat (Triticum aestivum L.) Productivity and Soil Properties in North-Western Himalaya. Journal of the Indian Society of Soil Science 62(3): 248-254.

19. Singh, A.K. (2007): Evaluation of soil quality under integrated nutrient management. Journal of the Indian Society of Soil Science 55(1): 58-61.

20. United Nations. (1997). Dryland degradation keeping hundreds of millions in poverty. Press Release: Secretariat of the United Nations Convention to Combat Desertification, Switzerland, Geneva.

21. United Nations. (2014). Department of Economics and Social Affairs, Population Division, World Population Prospects: The 2012 Revision, Methodology of United Nations and Projections, Estimates And Projections, Working Paper No. ESA/P/WP.235.

22. United States. (2014). Census Bureauhttp:/www.census.gov/population/international/accessed on $11^{\text {th }}$ April. 2014.

23. Upadhyay, V.B. and Vishwakarma, S.K. (2014): Long-term effect of integrated nutrient management in rice (Oryza sativa)-wheat (Triticum aestivum) cropping system. Indian Journal of Agronomy 59 (2): 209- 214. 